\title{
A Proposal of Inclusive Framework of the Nature of Science (NOS) Based on the 4 Themes of Scientific Literacy for K-12 School Science
}

\author{
Young Hee Lee* \\ University of Houston
}

\begin{abstract}
Although many researchers and science educators agree that understanding of the nature of science is essential in order for students to be a scientific literate person, it is not easy to compromise exactly what kind of understanding of the nature of science is required to achieve this goal (Smith \& Scharmann, 1999). This study discusses a theoretical background about the nature of science (NOS) including some consensus views of the NOS that several important U.S. educational reform documents and science researchers have presented over the past several decades. Finally, this study proposes an inclusive framework of the nature of science based on the four categories of scientific literacy, which are (1) science as a body of knowledge, (2) science as a way of investigating, (3) science as a way of thinking, and (4) the interaction of science, technology, and society. Each category of the framework includes several statements about the nature of science to describe each theme of the NOS. This framework is comprehensive and inclusive because it is suggested by examining several major U.S. national-level documents and in the publications of science education researchers presented about the nature of science. Significantly, many of the key ideas were added into category (4) and category (3), which indicates that the current literature stresses the relationship among science, technology, and society as well as the work of scientists.
\end{abstract}

Key words: the nature of science, scientific literacy, consensus views of NOS, a framework of the nature of science, the four themes of scientific literacy

\section{Introduction}

The nature of science has been a central theme in the science education over the past several decades. Science for All Americans (American Association for the Advancement of Science [AAAS], 1990) begins with a chapter on the nature of science, and the National Science Education Standards (NRC, 1996) stresses the importance of understanding the nature of science throughout the document. Currently, the Next Generation Science Standards (NGSS) address the importance of the understanding of the nature of science and the interaction of the three domains; science practice, crosscutting concepts, and the core disciplinary ideas to inform how to teach the nature of science in the Framework for K-12 Science Education (NRC, 2012). As such, helping $K-12$ students acquire an informed view of the nature of science has been a constant goal of science education for which extensive research and development efforts have been directed toward its achievement (Ackerson, Buzzelli, \& Donnelly, 2010; McDonald, 2010).

However, even though helping students achieve an adequate understanding of the nature of science has been a consistent goal for science education, research continues to show that a large majority of $\mathrm{K}-12$ students possess naïve views of the nature of science (Abd-ElKhalick \& Lederman, 2000; Lederman, 1992; Oliveira, Akerson, Colak, Pongsanon, \& Genel, 2012). Although many researchers and science educators agree that understanding of the nature of science is essential in order for students to be a scientific literate person, it is not easy to compromise exactly what kind of understanding of the nature of science is required in order to achieve this goal (Smith \& Scharmann, 1999). This is because the definition and views of the nature of science are abstract and complicated, since not only the nature of the 
scientific endeavor is multifaceted, complex, and dynamic, but also the conception of NOS has been reflected the changes of tradition in the philosophical, sociological, and historical aspects of science. Thus, the issue of how much and what aspects of the nature of science should be included in science curriculum and instruction to teach $\mathrm{K}-12$ students in school science are controversial but it is the priority task for science educators to achieve the goal.

The nature of science has been defined as the "epistemology of science, science as a way of knowing, or the values and beliefs of scientific knowledge and its development" (Lederman, 1992, p. 331). As researchers have explored many aspects of the nature of science to describe and inform science education about the character of science itself, they have developed a more encompassing definition. "The nature of science is a fertile hybrid arena which blends aspects of various social studies of science including the cognitive sciences such as psychology into a rich description of what science is, how it works, how scientists operate as a social group, and how society itself both directs and reacts to scientific endeavors" (McComas, Clough, \& Almazroa, 1998, p. 4).

For science educators, the term "nature of science (NOS)" is used to describe the issues addressed by the philosophy, history, sociology, and psychology of science as they apply to and impact science teaching and learning (McComas et al., 1998). In this view, the nature of science is a fundamental domain for guiding science educators in portraying science to students, and few people doubt that an authentic science curriculum must contain ideas about the nature of science.

It is important to note that individuals often conflate the NOS with science processes (AbdEl-Khalick, Bell, \& Ledermann, 1998). While scientific processes such as observing and inferring are related to the collection and interpretation of data in scientific activities, the NOS refers to the epistemological commitments underlying the activities of science. Consequently, it can be said that individuals' scientific processes are often influenced by ones' understanding of the NOS. Thus, even though there is overlap and interaction between science processes and NOS, nevertheless it is important to distinguish the two (Abd-El-Khalick \& Boujaoude, 1997).

This study discusses a theoretical background about the nature of science including some consensus views of the nature of science that several important U.S. educational reform documents and science educators have presented over the past several decades. In addition, the researcher proposes an inclusive framework of the nature of science based on the four categories of scientific literacy, which are (1) science as a body of knowledge, (2) science as a way of investigating, (3) science as a way of thinking, and (4) the interaction of science, technology, and society. This framework is suggested by examining several major U.S. national-level documents and in the publications of science education researchers presented about the nature of science. It is hoped that this synthetic and inclusive framework can be used to teach authentic views of the nature of science for science teachers and students rather than engaging them in puzzling discussion about the nature of science in science classrooms.

\section{A Theoretical Background about the Nature of Science (NOS) \\ 1. Why Should an Understanding of the NOS be a Goal of Science Education?}

As aforementioned, helping students develop adequate understandings the nature of science has been a long-standing concern of science educators and has recently been reemphasized in the national reform efforts in science education (AAAS, 1990, 1993; National Research Council [NRC], 1996, 2012). If so, why is it important to understand the nature of science? Even though 
many answers have been given to the question, one of the most important reasons is that this understanding of the nature of science is crucial to responsible personal decision-making and effective local and global citizenship (Smith \& Scharmann, 1999).

The preparation of scientifically literate students is a persistent goal of science education (American Association for the Advancement of Science [AAAS], 1990, 1993; Millar \& Osborne, 1998). Moreover, an adequate understanding of nature of science is a central element of scientific literacy (AAAS, 1990, 1993; National Science Teachers Association [NSTA], 1982). In addition to its fundamental value, Driver, Leach, Miller, and Scott (1996) contended that it enhances learning of science content, generates interest in science, and develops students' ability to make informed decisions on socioscientific issues based on careful consideration of evidence.

In Benchmarks for Scientific Literacy (AAAS, 1993), it is contended that:

When people know how scientists go about their work and reach scientific conclusions and what the limitations of such conclusions are, they are more likely to react thoughtfully to scientific claims and less likely to reject them out of hand or accept them uncritically. (p. 3)

As such, there is significant agreement among science educators in the science education community that understanding science and the how science works is important. Thus, few people deny that it is critical to include appropriate level of the nature of science in science education including curriculum reform and professional development so that students can understand and appreciate the scientific enterprise.

\section{Disagreement and Change of Conception for the Nature of Science}

Although typically nature of science refers to the epistemological aspects of science, science as a way of knowing, or the values and beliefs to the development of scientific knowledge (Lederman, 1992), philosophers, historians, and sociologists of science, as well as science educators are quick to disagree on a specific definition for the nature of science (Abd-ElKhalick et al., 1998). This lack of agreement is not surprising given the complex nature of the scientific endeavor. Despite the lack of consensus about a specific definition for the nature of science, recently the science education community has sought to define what key nature of science ideas are appropriate for the inclusion in science curriculum and consensus views have begun to emerge from the extensive literature in history and philosophy of science (McComas, 2005).

In addition, because the view of the nature of science is reflected emphasis and focus in the fields of philosophy, history, and sociology of science, conceptions of NOS have changed with developments in various scientific disciplines (Abd-El-Khalick \& Lederman, 2000). According to Giere (1988), work in the philosophy and sociology of science in the twentieth century can be divided into two periods separated by Kuhn's (1962) Structure of Scientific Revolutions. During the first half of the twentieth century, PreKuhnian philosophy of science was dominated by the work of logical empiricists. In this tradition, philosophers were interested in developing a normative logical account to justify scientific claims rather than a descriptive account of how science actually works. This tradition emphasized the history of scientific 'ideas' with unnecessary regard to the context within which such ideas were developed (Abd-El-khalick \& Lederman, 2000). Meanwhile, Kuhn's (1962) paradigmatic and revolution approach marked a shift among philosophers and historians of science emphasizing the context of justification to delving into the context of discovery. In this tradition, philosophers of science invoked 
sociological, psychological, or cultural elements in their attempts to provide accounts of the scientific endeavor within their large social and cultural contexts. It is plausible to claim that changes in conceptualizing NOS within philosophical, sociological and historical emphases are mirrored in the ways the science education community has defined the term 'NOS' during the past twentieth century (AbdEl-Khalick \& Lederman, 2000).

\section{Consensus Views Regarding the Nature of Science (NOS) from the Literature}

According to Smith and Scharmann (1999), it should be clear that adjusting the level of treatment of the nature of science to match the level of knowledge, abilities, and intellectual development of our students is necessary and appropriate. Researchers also point out that disagreements about the specific definition of NOS among philosophers of science, historians of science, and science educators are far too abstract and irrelevant for $\mathrm{K}-12$ students to understand (Abd-El-Khalick, Bell., \& Lederman, 1998). Thus, it is essential to come up with an accessible level of generality about the nature of science that is accessible to $\mathrm{K}-12$ students and also relevant to their daily lives (Abd-El-Khalick at al., 1998).

It has been more than 20 years since Laudan, Donovan, Laudan, R., Barker, Brown, Leplin, Thagard., \& Wykstra. (1986) stated following:

\footnotetext{
"We have no well-confirmed general picture of how science works, no theory of science worthy of general assent $\cdots$. If any extant position does provide a viable understanding of how science operates, we are far from being able to identify which it is." (p. 142)
}

Because of the great position of the nature of science in science education for the past twenty years, currently we have extensive researches and documents that emphasize on the nature of science and some consensus views of the nature of science that many science educators agree with.

\section{1) Consensus NOS Views from National-Level Documents}

Fortunately, since many scholars have researched and written about the nature of science and also national-level documents such as Science for All Americans (AAAS, 1990), Benchmarks for Science Literacy (AAAS, 1993), the National Science Education Standards (NRC, 1996) that emphasize the major role of the nature of science in science education, there are some general consensus views among science educators that certain aspects of authentic science should be integrated into the science curriculum and instruction (Lederman \& AbdEl-Khalick, 1998; Schwartz, Lederman, \& Thompson, 2001). Even though it may not be possible to present all the views of the nature of science published in science education in this study, there is a need to look over some important consensus ideas in order to identify what authentic views of nature of science currently we have.

First, many reform efforts emphasize the importance of understanding the nature of science (American Association for the Advancement of Science [AAAS], 1990, 1993; National Research Council [NRC], 1996, 2000). Throughout the reform documents Benchmarks for Science Literacy (AAAS, 1993) and National Science Education Standards (NRC, 1996) can be found the statements that reflect what scientists, philosophers of science, historians of science, and science educators consider fundamental aspects of the nature of science.

"Science distinguishes itself from other ways of knowing and from other bodies of knowledge through the use of empirical standards, logical arguments, and skepticism, as scientists strive for the best possible explanations about the natural world" (NRC, 1996, p. 201). 
This quote indicates that "science is a way of coming to understand the world in which we live" and further, that it is unique in that it has standards and practices that create ideas to explain phenomena and to expect outcomes (Chiappetta \& Koballa, 2002, p. 5).

The national reform document Science for All Americans (AAAS, 1990) divides the nature of science into three major subjects: the scientific worldview, scientific methods of inquiry, and the nature of the scientific enterprise (see Table 1). The scientific worldview that has evolved indicates that scientists share certain basic beliefs and attitudes about what they do and how they view their work with the nature of the world (AAAS, 1990). Scientific inquiry distinguishes science from other human enterprises (Chiappetta \& Koballa, 2002). Scientists differ in phenomena they investigate; also differ by methodology, or how they go about their work (AAAS, 1990). Even though there is no fixed set of steps that scientists always use to obtain scientific knowledge, there are certain features of science that give it a distinctive character as a field of inquiry. Also, everyone can think scientifically in everyday life. The scientific enterprise shows that science has individual, social, and institutional scope as a human enterprise. Scientific activity is one of the main characters of the contemporary world, and it distinguishes today from earlier centuries (AAAS, 1990).

Similarly, one of the biggest teacher organizations in the United States, National Science Teacher Association (NSTA), presents the nine statements of the nature of science in order for science teachers to inform the core ideas regarding to the scientific enterprise. These nice ideas are comprehensive and easy to understand so that science teachers apply and implement the understanding in their science classrooms. Table 1 shows the summary of the statements of the nature of science in nationallevel documents in U.S.

\section{2) Consensus NOS Views from Science Educators' Publications}

In addition to the consensus concerning the nature of science proposed by national-level documents, science education researchers presented a list of views of nature of science that emerged from numerous scientific researches. Lederman, Abd-El-Khalick, Bell, Schwartz, \& Akerson (2001) suggested the eight characteristics of nature of science (see Table 2). Also, science education researchers who have examined the literature and conducted surveys among their colleagues report a high level of consensus regarding salient aspects of what constitutes science (Osborn, Collins, Ratcliffe, Millar, \& Duschl, 2003; McComas, 1998; Lederman, 2002; and McComas, Clough, \& Almazroa, 1998; Felske, 2000). Currently, McComas (2005) offered a suggested list of core NOS ideas appropriate to inform K 12 curriculum development, instruction, and teacher education. Also, Bartholomew, Osborne, \& Ratcliffe (2004) proposed nine statements of the nature of science based on their previous research (Osborn, Collins, Ratcliffe, Millar, \& Duschl, 2003). Table 2 shows the statements of the nature of science that science education researchers published to suggest the core ideas of the nature of science for $\mathrm{K}-12$ school science.

\section{Four Themes (Categories) of the Science Literacy}

In spite of significant progress toward characterizing the nature of science, sometimes reading about the nature of science can still become confusing because the nature of science is neither universal nor stable (Lederman, 1992). Yet one of the central responsibilities of science teachers remains to provide an accurate description of science rather than to engage students in the arcane arguments that occur among philosophers of science (McComas, Clough, \& Almazroa, 1998). Fortunately, there are themes of scientific literacy that science educators and scientists recognize and accept as 


\section{Table 1}

NOS Statements in U.S. National-Level Documents

\begin{tabular}{|c|c|}
\hline Documents & NOS Statements \\
\hline $\begin{array}{l}\text { Science for All } \\
\text { Americans (AAAS, } \\
\text { 1990) }\end{array}$ & $\begin{array}{l}\text { The Scientific Worldview } \\
\text { - The world is understandable. } \\
\text { - Scientific ideas are subject to change. } \\
\text { - Scientific knowledge is durable. } \\
\text { - Science cannot provide complete answers to all questions. } \\
\text { Scientific Inquiry } \\
\text { - Science demands evidence. } \\
\text { - Science is a blend of logic and imagination. } \\
\text { - Science explains and predicts. } \\
\text { - Scientists try to identify and avoid bias. } \\
\text { - Science is not authoritarian. } \\
\text { The Scientific Enterprise } \\
\text { - Science is a complex social activity. } \\
\text { - Science is organized into content disciplines and is conducted in various } \\
\text { - Thstitutions. } \\
\text { - Scientists participate in public affairs both as specialists and citizens. }\end{array}$ \\
\hline $\begin{array}{l}\text { Benchmarks for } \\
\text { Science Literacy } \\
\text { (AAAS, 1993) }\end{array}$ & $\begin{array}{l}\text { A. The Scientific World View } \\
\text { B. Scientific Inquiry } \\
\text { C. The Scientific Enterprise }\end{array}$ \\
\hline $\begin{array}{l}\text { National Science } \\
\text { Education Standards } \\
\text { (NRC, 1996) }\end{array}$ & $\begin{array}{l}\text { Level } \mathrm{K}-4 \\
\text { • Science as a human endeavor } \\
\text { Level } 5-8 \\
\text { - Science as a human endeavor } \\
\text { - Nature of Science } \\
\text { - History of Science } \\
\text { Level } 9-12 \\
\text { - Science as a human endeavor } \\
\text { - Nature of Scientific Knowledge } \\
\text { - Historical Perspectives }\end{array}$ \\
\hline $\begin{array}{l}\text { National Science } \\
\text { Teachers } \\
\text { Association } \\
\text { (NSTA, 2000) }\end{array}$ & $\begin{array}{l}\text { - Scientific knowledge is tentative. } \\
\text { - There is no single step-by-step scientific method. } \\
\text { - Creativity is a vital component for producing scientific knowledge. } \\
\text { - Science precludes supernatural elements for producing scientific knowledge. } \\
\text { - Laws are generations describing phenomena while theories are explanations of it. } \\
\text { - Science is conducted corporately. } \\
\text { - Science is affected by existing scientific knowledge and social/cultural context. } \\
\text { - Science has changed both evolutionally and revolutionally. } \\
\text { - Basic scientific research is not directly concerned with practical outcomes. }\end{array}$ \\
\hline
\end{tabular}

a useful description of science. The four themes of scientific literacy are: (1) science as a body of knowledge, (2) science as a way of investigating, (3) science as a way of thinking, and (4) the interaction of science, technology, and society, which were put forth by Collette and Chiappetta (1984) to describe and define science for preservice middle and high school science teachers.
Since it was developed, it has been used many times to analyze the content of science textbooks for the past several decades (Chiappetta, Fillman,, \& Sethna, 1991; Chiappetta \& Fillman, 2005). Further, the four domains of science have been refined to reflect the many dimensions of science that philosophers, historians, and scientists have written about. The original four 


\section{Table 2}

\section{NOS Statements in Publications of Science Educators}

\begin{tabular}{|c|c|}
\hline $\begin{array}{c}\text { Authors of } \\
\text { Publications }\end{array}$ & NOS Statements \\
\hline $\begin{array}{l}\text { Lederman, Abd-El- } \\
\text { Khalick, Bell, } \\
\text { Schwartz, \& } \\
\text { Akerson (2001) }\end{array}$ & $\begin{array}{l}\text { 1. Science knowledge is tentative. } \\
\text { 2. Science knowledge has basis in empirical evidence. } \\
\text { 3. Scientific laws and theories are separate kinds of scientific knowledge. } \\
\text { 4. Scientific knowledge is based upon both observation and inference. } \\
\text { 5. Scientific knowledge is created from human imagination and logical } \\
\text { reasoning. } \\
\text { 6. Scientific knowledge can be obtained by a variety of scientific methods. } \\
\text { 7. Scientific knowledge is inherently subjective and based on interpretation. } \\
\text { 8. Science is a human endeavor influenced by society and culture. }\end{array}$ \\
\hline McComas (2005) & $\begin{array}{l}\text { 1. Science demands and relies on empirical evidence. } \\
\text { 2. Knowledge production in science shares many common factors and shared } \\
\text { habits of minds, norms, logical thinking and methods } \\
\text { 3. Scientific knowledge is tentative but durable } \\
\text { 4. Laws and theories are related but distinct kinds of scientific knowledge. } \\
\text { 5. Science has a creative component. } \\
\text { 6. Science has a subjective element. } \\
\text { 7. There are historical, cultural, and social influences on science. } \\
\text { 8. Science and technology impact each other, but they are not the same. } \\
\text { 9. Science and its methods cannot answer all questions. }\end{array}$ \\
\hline
\end{tabular}

Bartholomew, Osborne, and Ratcliffe (2004)

1. Experiments are used to test ideas.

2. Scientific knowledge is subject to change.

3. Science uses a range of methods and there is no one scientific method.

4. Developing hypotheses and predictions is essential to the development of new knowledge.

5. Scientific knowledge is developed with its history.

6. Science involves creativity and imagination.

7. New scientific knowledge emerges from a continual and cyclic process of asking questions and seeking answers.

8. Scientific knowledge emerges from simply from the data but a process of interpretation and theory building, and often scientists come from different interpretations.

9. Scientific work is a communal and competitive activity.

Ackerson, Morrison, \& McDuffie (2006)
1. Scientific knowledge is tentative, that is, is subject to change.

2. There are multiple methods of inquiry, and those methods require empirical evidence.

3. Creativity is important in developing knowledge.

4. Scientific knowledge is subjective.

5. Scientific knowledge is developed within a social and cultural context.

6. Theory is evidence-based explanation of phenomena while law is an evidencebased description of it.

7. Inferences are explanations for observation. themes including descriptors are described in detail below.

\section{1) Science as a body of knowledge}

The body of knowledge represents the collection of ideas about the natural and physical world from many scientific fields. The facts, concepts, principles, laws, hypotheses, theories, and models structure the content of scientific knowledge.

\section{2) Science as a way of investigating}

This aspect of the nature of science reflects the active learning and inquiry, which involves 
the student in such processes of science as observing, measuring, classifying, inferring, recording data, making calculations, and experimenting. Science as a way of investigating utilizes many approaches to constructing scientific knowledge.

\section{3) Science as a way of thinking}

This aspect of the nature of science details how the scientific enterprise operates (Chiappetta et al., 1991). Beliefs, curiosity, imagination, reasoning, cause-and effect relationships, self- examination and skepticism, and objectivity and open-mindedness are all ways of thinking that occur in science.

\section{4) Science's interactions with technology and society}

This aspect of the nature of science shows the relationships among science, technology, and society. It represents the effects or impacts of science on society and how technology influences on science and society. Some social issues related to this aspect of the nature of science can be discussed.

Because an adequate understanding of nature of science is an essential component of scientific literacy (AAAS, 1990, 1993; National Science Teachers Association [NSTA], 1982), developing or organizing a framework of the nature of science based on the scientific literacy themes must be reasonable and understandable. Sine characterizing the nature of science may be abstract and complex for $\mathrm{K}-12$ students to be taught, there is a need to organize and reconstruct the concepts of the nature of science in terms of understandable and appropriate way to introduce science teachers and students in $\mathrm{K}-$ 12 school science. In this view, the four categories of scientific literacy must be relevant and accessible for science teachers so that they can implement the four domains to teach a variety of views of science in the classroom. To establish an inclusive view of the nature of science, the various explanations of the nature of science from national-level documents and publications of science educators can be examined and filtered through the categories of scientific literacy.

\section{Developing of an Inclusive Framework of the NOS from Literature}

\section{Examining Literature to Identify Key Ideas about the Nature of Science}

The researcher examined the nature of science chapters in national-level documents and in the publications of science education researchers to identify a key idea or description about the nature of science. Those key ideas and descriptions are terms of summaries how statements of the documents describe the nature of science in the chapters. The first set of documents examined were the nature of science chapter in Science for All Americans (AAAS, 1990), Benchmarks for Science Literacy (AAAS, 1993), the National Science Education Standards (NRC, 1996), and the Statements of Nature of Science (NSTA, 2000). The second set of publications were the eight characteristics of the nature of science by Lederman, Abd El Khalick, Bell, and Akerson (2001), the list of core NOS ideas for $\mathrm{K}-12$ curriculum development, instruction, and teacher education by McComas (2005) and the nine themes of the nature of science by Bartholomew, Osborn, \& Ratcliffe (2004), and the seven statements by Ackerson, Morrison, \& McDuffie (2006). Table 3 indicates the summary of the key ideas found in literature.

\section{Categorizing the Key Terms into the Four Categories of the Scientific Literacy}

From the literature examined in this study, the key ideas or descriptors of the nature of science were identified and then categorized into the four categories of scientific literacy in terms of the nature of terms. For instance, if the 


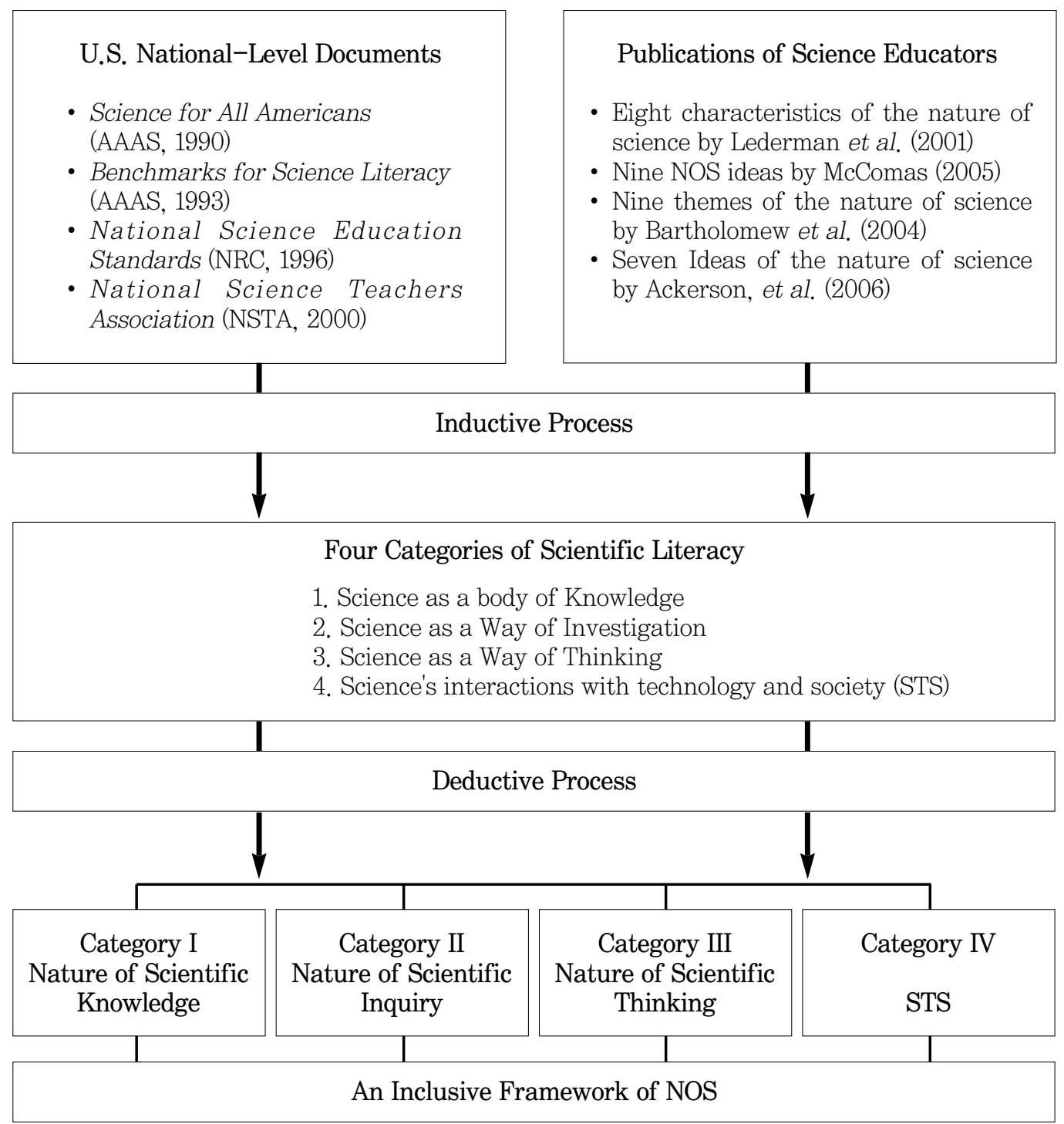

Fig. 1 A Process of Developing an Inclusive Framework of NOS

researcher identifies the term, "tentativeness of scientific knowledge" from one of the source of literature, it was categorized into the Category I, Science as a Body of Knowledge because this term describes the nature of scientific knowledge, which is the first theme among the four categories of the scientific literacy. Through this process, all the descriptions and terms from the literature were categorized into one of the four categories in scientific literacy. Since the four categories of scientific literacy are comprehensive and inclusive, many of terms were inserted into the existing themes among the four themes. When a new term or descriptor appeared more than once in the literature, the descriptors were added into one of the four themes of framework in terms of the characteristics of terms. For example, the descriptor, "tentativeness of scientific knowledge" was added into the Category I, 


\section{Table 3}

NOS Key Descriptions in the Literature Examined

\begin{tabular}{|c|c|}
\hline Publications & "Key Terms (Descriptors) \\
\hline $\begin{array}{l}\text { Science for All } \\
\text { Americans (AAAS, } \\
\text { 1990) }\end{array}$ & $\begin{array}{l}\text { - Understanding of nature } \\
\text { - Tentativeness of scientific knowledge } \\
\text { - Durability of scientific knowledge } \\
\text { - Limitation of science } \\
\text { - Empirical basis of science } \\
\text { - Reasoning and imagination } \\
\text { - Explanation and prediction } \\
\text { - Characteristics of scientists } \\
\text { - Social/cultural effects in science } \\
\text { - Contribution of diversity } \\
\text { - Ethics in science } \\
\text { - Characteristics of scientists }\end{array}$ \\
\hline $\begin{array}{l}\text { Benchmarks for } \\
\text { Science Literacy } \\
\text { (AAAS, 1993) }\end{array}$ & $\begin{array}{l}\text { - Scientific thinking } \\
\text { - Scientific investigation } \\
\text { - STS }\end{array}$ \\
\hline $\begin{array}{l}\text { National Science } \\
\text { Education } \\
\text { Standards (NRC, } \\
\text { 1996) }\end{array}$ & $\begin{array}{l}\text { - Social/cultural effects in science } \\
\text { - Nature of scientific knowledge } \\
\text { - Historical development in science }\end{array}$ \\
\hline $\begin{array}{l}\text { National Science } \\
\text { Teachers } \\
\text { Association (NSTA, } \\
\text { 2000) }\end{array}$ & $\begin{array}{l}\text { - Tentativeness of scientific knowledge } \\
\text { - A variety of scientific methods } \\
\text { - Importance of creativity } \\
\text { - Empirical basis of science } \\
\text { - Distinctness of scientific knowledge } \\
\text { - Contribution of diversity } \\
\text { - Social/cultural effects in science } \\
\text { - Tentativeness of science } \\
\text { - Usefulness of science }\end{array}$ \\
\hline $\begin{array}{l}\text { Lederman, Abd-El- } \\
\text { Khalick, Bell, } \\
\text { Schwartz, \& } \\
\text { Akerson (2001) }\end{array}$ & $\begin{array}{l}\text { - Tentativeness of scientific knowledge } \\
\text { - Empirical basis in science } \\
\text { - Distinctness of scientific knowledge } \\
\text { - Observation and inference } \\
\text { - Areativity and reasoning } \\
\text { - Interiety of scientific methods } \\
\text { - Social/cultural effects in science }\end{array}$ \\
\hline McComas (2005) & $\begin{array}{l}\text { - Empirical basis in science } \\
\text { - Creativity, reasoning, } \\
\text { - A variety of scientific methods } \\
\text { - Importance of observation and inference } \\
\text { - Tentativeness of scientific knowledge } \\
\text { - Durability of scientific knowledge } \\
\text { - Distinctness of scientific knowledge } \\
\text { - Socialivity } \\
\text { - The relationshionsfects in science } \\
\text { - Limitations of science }\end{array}$ \\
\hline $\begin{array}{l}\text { Bartholomew, } \\
\text { Osborne, and } \\
\text { Ratcliffe, (2004) }\end{array}$ & $\begin{array}{l}\text { - Cause and effect relationship } \\
\text { - Tentativeness } \\
\text { - A variety of scientific methods } \\
\text { - Importance of Scientific experiment }\end{array}$ \\
\hline
\end{tabular}




\begin{tabular}{l|l}
\hline & - Historical development in science \\
& - Creativity and imagination \\
& - Sature of development of scientific knowledge \\
\hline Ackerson, Morrison, & - Tentativeness of scientific knowledge \\
\& McDuffie (2006) & - Eariety of scientific methods \\
& - Creativity evidence in science \\
& - Social/cultural effects in science \\
& - Importance of obsentific knowledge \\
\hline
\end{tabular}

sources of literature, such as Science for All Americans (AAAS, 1990), Benchmarks for Science Literacy (AAAS, 1993), the National Science Education Standards (NRC, 1996), the work of Lederman, Abd El Khalick, Bell, and Akerson (2001), and the report by McComas (2005)

\section{Proposing the Summary of the Nature of Science from the Key Terms in Each Category of Scientific Literacy}

After categorizing the terms of science from the literature, the researcher examined what key terms of nature of science were found in each category. Because many of key terms found were overlapped and repeated in different sources of literature, less than 6-7 key terms was found in each category after reviewing all the descriptors. Finally, the researcher proposed several statements of the nature of science through the process of combining all key ideas based on the four categories of scientific literacy (see Table 4). Finally, table 4 presents the summary of the statements of nature of science through the process of blending all key ideas in terms of the four categories of scientific literacy.

\section{Results and Discussions}

Synthesizing a framework of the nature of science based on the four categories of the scientific literacy was productive because several consensus views of the nature of science in each category were identified from the national-level standards and science education researcher reports. The literature related to the nature of science was examined in order to determine what recommendations and findings from national committees and science have to be included into the original four categories of scientific literacy. Consequently, many key ideas were added, which enhanced the framework by counting many aspects of the nature of science from the current literature in science education.

Specifically, the category I, Nature of scientific knowledge, explains that science collects of ideas about the natural and physical world from many scientific fields and how a variety of scientific knowledge such as facts, concepts, laws, hypotheses, theories, and models have been evolved from the process of scientific inquiry. Also, this aspect of the nature of science shows the importance of science as not only the process of science but also the product of science. Many of the literature emphasize the tentativeness of scientific knowledge as well as the existence of different types of the scientific knowledge.

The Category II, Nature of scientific Inquiry, stresses the process of scientific investigation that was conducted by scientists. Specifically, this aspect of the nature of science reflects the active process of inquiry, which involves the scientists in such science process skills as observing, measuring, classifying, inferring, recording data, making calculations, and experimenting. Current science documents heavily emphasize the importance of a variety of scientific methods even though experiments are commonly used to investigate the nature in 


\section{Table 4}

\section{An Inclusive Framework of Nature of Science (NOS) based on the Four Categories}

\section{Category I: Nature of scientific knowledge}

1) Science is organized into content disciplines such as facts, concepts, laws, theories, etc.

2) Scientific knowledge explains and predicts the nature.

3) Scientific knowledge is tentative but durable.

4) There are different types of knowledge in science (laws and theories are different).

5) New scientific knowledge emerges from the process of scientific inquiry.

\section{Category II: Nature of scientific inquiry}

1) Science is based on empirical evidence.

2) Science relies on observation and inference.

3) There are various scientific methods in science (no single step-by-step scientific method)

4) Experiments are important to test ideas using science process skills.

\section{Category III: Nature of scientific thinking}

1) Both reasoning and imagination (creativity) are important in science.

2) Scientists are not totally objective but try to avoid bias.

3) Scientific knowledge is based on interpretation.

4) Scientific knowledge is developed with its history.

5) Skepticism and criticism are critical in scientific thinking.

\section{Category IV: Nature of interactions among science, technology, and society (STS)}

1) Science can be used in society both positively and negatively.

2) Science and technology impact each other but they are not the same

3) Science is a complex social activity.

4) There are social and cultural influences on science.

5) Science and its method cannot solve all problems in society (limitation of science)

6) Science is conducted corporately (contribution of diversity)

7) There are ethical principles in science.

8) Scientists participate in public affairs both as specialists and citizen.

science. The original four categories of scientific literacy used the term "scientific investigation" for the second category but the researcher changed the term as the "scientific inquiry" since the term, inquiry is more exclusively used in science education to describe how scientist work.

The Category III, Nature of scientific thinking, describes the characteristics of scientists and how the scientific enterprise operates. Science education documents examined in the study point out the fact that scientist are not only specialists but also citizen in the society. Also, this aspect of the nature of science stresses the characteristics of scientists such as curiosity, imagination, reasoning, skepticism, objectivity and open-mindedness as the ways of thinking that occur in science.

Finally, the Category IV, Nature of interactions among science, technology, and society (STS), shows the relationships among science, technology, and society and represents the impacts of science on society and how technology influences on science and society. Also, this aspect of the nature of science indicates that science and technology are not the 
same, which is the distinctness of science and technology. Significantly, this aspect of the nature of science stresses the negative impacts of science as well as the limitation of science. Some social issues related to the culture and ethics also were presented in this category. Interestingly, many of the key ideas were added into this category from the literature examined, which indicate that the national-level documents and the science educational research literature stress the relationship among science, technology, and society as well as the work of scientists -- their way of thinking as well as their interaction with others as a community of professionals.

\section{Conclusions and Implications}

Even though current reform documents have attempted to promote understanding of how science works for teachers and students, without a holistic understanding of the nature of science and the evaluation of the science curriculum and documents for an adequate level of inclusion of the nature of science, reforms aimed at developing scientific literacy will likely remain deficient.

In this view, there are two main intentions for this study. One of the objectives of this study is to provide a theoretical background for the nature of science including some consensus views of the nature of science from U.S. national-level documents and science education research reports that currently many science educators acknowledged as authentic views of nature of science. As stated in the beginning of the study, understanding the nature of science has been strongly emphasized in science education as one of central goals for many years. To achieve this goal, as the first step science teachers and educators should understand what the nature of science is and why it is an essential goal in science education. As such, this article can contribute to inform science teachers and educators a theoretical background for understanding the nature of science to achieve the goal for understanding the nature of science.

The second purpose of this study is to propose an inclusive framework of nature of science by examining some central literatures in science education. It is important to recognize the national-level documents in order to address the majority of the nature of science frameworks, components and structures. However, those documents do not fully reflect an understanding of the nature of science that is supported by scholarship from the fields of the philosophy, history, and sociology of science (Abd-ElKhalick, 2000; Glasson \& Bentley, 1999; McComas \& Olson, 2000; Schwartz, Lederman, \& Crawford, 2000). Likewise, even though many researchers suggested a list of views of the nature of science, there is no broad or general consensus concerning the contents, level, and scope of the nature of science in $\mathrm{K}-12$ science (Park, 2007). Thus, it is essential to examine not only the educational reform documents but also science educators' reports regarding to the nature of science to compromise an authentic view of the nature of science.

In addition to compromising an authentic view of the nature of science, the framework can be used to assess science curriculum and instruction regarding to the nature of science. Synthesizing the framework of the nature of science based on the four categories of scientific literacy has contributed to the expansion of consensus views on the nature of science as an exhaustive and inclusive instructional framework for science curriculum assessment because it was proposed by examining several important literatures in science education. Since science educators need to assess science curricula and professional development to include the recommendations of the national reform documents as well as the aspects of the philosophy, history, and sociology of science (Glasson \& Bentley, 1999), it is critical to have a reliable and valid tool for evaluating the science curriculum. Therefore, it is hoped that this 
synthetic and inclusive framework can serve to be used to understand the holistic views of the nature of science and also to assess science curriculum for their inclusion of many aspects of the nature of science as a conceptual framework.

Future research is needed in order to analyze science curriculum and instruction to identify what kind of the views of the nature of science is included in the lessons or textbooks in many different grade levels and subjects in science. For example, how well do science textbooks address the issue of how scientific knowledge is discovered and developed? How do the elementary and middle school science textbooks present the many dimensions of science?

\section{Reference}

Abd-El-Khalick, F. (2000, April). Explicit reflective content-embedded nature of science instruction: Abandoning scientism, but..Paper presented at the annual meeting of the National Association for Research in Science Teaching, New Orleans, LA.

Abd-El-Khalick, F., \& Akerson, V. L. (2004). Learning about nature of science as conceptual change: Factors that mediate the development of preservice elementary teachers' views of nature of science. Science Education, 88(5), 785-810.

Abd-El-Khalick, F., Bell, R. L., \& Lederman, N. G. (1998). The nature of science and instructional practice: making the unnatural natural. Science Education, 82, 417-436.

Abd-El-Khalick, F., \& Boujaoude, S. (1997). An exploratory study of the knowledge base for science teaching. Journal of Research in Science Teaching, 34, 673-699.

Abd-El-Khalick, F., \& Lederman, N. G. (2000). The influence of history of science on students' view of nature of science. Journal of Research in Science Teaching, 37, 1057-1095.

Akerson, V. L., Buzzelli, C., \& Donnelly, L. A. (2010). On the nature of teaching nature of science: Preservice early childhood teachers' instruction in preschool and elementary settings.
Journal of Research in Science Teaching, 47, 213-233.

Ackerson, V. L., Morrison, J.A., \& McDuffie, A. R. (2006). One course is not enough: Preservice elementary teachers' retention of improved views of nature of science. Journal of Research in Science Teaching, 43, 194-213.

American Association for the Advancement of Science (AAAS). (1993). Benchmarks for scientific literacy. New York: Oxford University Press.

American Association for the Advancement of Science (AAAS). (1990). Science for all Americans. New York: Oxford University Press.

Bartholomew, H., Osborne, J., \& Ratcliffe, M. (2004). Teaching pupils "ideas-about-science": Five dimensions of effective practice. Science Education, 88, 655-682.

Chiappetta, E. L., \& Fillman, D. A. (2005). Analysis of five high school biology textbooks used in the United States for inclusion of the nature of science. Paper presented at the National Association for Research in Science Teaching meeting. Dallas, TX.

Chiappetta, E. L., Fillman, D. A., \& Sethna, G. H. (1991). A method to quantify major themes of scientific literacy in science textbooks. Journal of Research in Science Teaching, 28, 713-725.

Chiappetta, E.L., \& Koballa, Jr., T. R. (2002). Science instruction in the middle and secondary school ( $5^{\text {th }}$ ed.). Upper Saddle River, NJ: Pearson Education.

Chiappetta, E. L., Sethna, G. H., \& Fillman, D. A. (1991). A qualitative analysis of high school chemistry textbooks for scientific literacy themes and expository learning aids. Journal of Research in Science Teaching, 28, 936-951.

Collette, A., \& Chiappetta, L. E. (1984). Science Instruction in the middle and secondary schools. St. Louis, MO: Times Millor/Mosby.

Driver, R., Leach, J., Miller, A., \& Scott, P. (1996). Young peoples images of science. Buckingham, England: Open University Press.

Felske, D. D. (2000). A historical examination of the nature of science and its consensus as presented in the benchmarks for science literacy 
and national science education standards. Doctoral Dissertation. Houston, TX: University of Houston.

Giere, R. N. (1988). Exploring science: A cognitive approach. Chicago: The University of Chicago Press.

Glasson, G., \& Bently, M. (1999). Scientists' views of the nature of science in relation to their own research. Paper presented at the annual meeting of the National Association for Research in Science Teaching, Boston, MA.

Kuhn, T. S. (1962). The Structure of Scientific Revolutions (Chicago: The University of Chicago Press).

Laudan, L., Donova, A., Laudan, R., Barker, P., Brown, H., Leplin, J., Thagard, P., \& Wykstra, S. (1986). Scientific chamge: Philosophical models and historical research, 69, 141-223.

National Research Council (NRC). (1996). National Science Education Standards. Washington, DC: National Academy Press.

Lederman, N. G. (2002). The state of science education: Subject matter without context. Electronic Journal of Science Education [OnLine], 3(2), Retrieved December 5, 2006 from. http://unr.edu/homepage/jcannon/ejse/ejse.html

Lederman, N. G. (1992). Students' and teachers' conceptions about the nature of science: A review of the research. Journal of Research in Science Teaching, 29, 331-359.

Lederman, N. G., \& Abd-El-Khalick, F. (1998). Avoiding de-natured science: Activities that promote understandings of the nature of science. InW. McComas (Ed.). The nature of science in science education: Rationales and strategies (pp. 83-126). Doedrecht, The Netherlands: Kluwer Academic.

Lederman, N. G., Abd-El-Khalick, F., Bell, R. L., Schwartz, R. S., \& Akerson, V. L. (2001, March). Assessing the un-assessable: View of the nature of science questionnaire (VNOS). A paper presented at the National Association for Research in Science Teaching, St. Louis, MO.

McComas, W. F. (2005). Seeking NOS standards: What content consensus exists in popular books on the nature of science? Paper presented at the National Association for Research in Science Teaching meeting. Dallas, TX.

McComas, W. F. (1998). The principal elements of the nature of science: Dispelling the myths of science. In W. F. McComas (Ed.). The Nature of Science in Science Education: Rationales and Strategies (p. 53-70). Dordrecht: Kluwer.

McComas, W.F., Clough, M. P., \& \& Almazroa, H. (1998). A review of the role and character of the nature of science in science education. In W. F. McComas (Ed.). The Nature of Science in Science Education: Rationales and Strategies (p.3-39). Dordrecht: Kluwer.

McComas, W., \& Olson, J. (2000). The nature of science in international science education standards documents. In W. McComas (Ed), The nature of science in science education rationales and strategies (p. 41-52). Boston, MA: Kluwer.

McDonald, C. V. (2010). The influence of explicit nature of science and argumentation instruction on preservice teachers' views of nature of science. Journal of Research in Science Teaching, 47, 1137-1164.

Miller, R., \& Osborne, J. (Eds.). (1998). Beyond 2000: Science education for the future (London: King's College).

National Research Council (NRC). (1996). National Science Education Standards. Washington, DC: National Academy Press.

National Research Council (NRC). (2000). How people learn. Bridging research and practice. Washington, DC: National Academy Press.

National Research Council (NRC). (2012). A framework for $\mathrm{K}-12$ science education, DC: National Academy Press.

National Science Teachers Association (NSTA). (1982). Science-Technology-Society: Science Education for the 1980s (An NSTA position statement). Washington, DC: Author.

Oliveira, A. W., Akerson, V. L., Colak, H., Pongsanon, K., \& Genel, A. (2012). The implicit 
communication of nature of science and epistemology during inquiry discussion. Science Education, 96, 652-684.

Osborne, J., Collins, S., Ratcliffe., Miller, R., \& Duschl, R. (2003). What "ideas-about-science" should be taught in school science? A Delphi study of the expert community. Journal of Research in Science Teaching, 40, 692-720.

Park, J. (2007). A study of new modles for scientific inquiry activity through understanding the nature of science (NOS). Journal of the Korean Association for Research in Science Education, 27. 153-167.

Schwartz, R. S., Lederman, N. G., \& Crawford, B. (2000, April). Understanding the nature of science through scientific inquiry: An explicit approach to bridge the gap. Paper presented at the annual meeting of the National Association for Research in Science Teaching, New Orleans, LA.

Schwartz, R. S., Lederman, N. G., \& Thompson,T. (2001, March). Grade nine students' views of nature of science and scientific inquiry: the effects of an inquiry-enthusiast's approach to teaching science as inquiry. A paper presented at the National Association for Research in Science Teaching, St. Louis, MO.

Smith, M. U., \& Scharmann, L. C. (1999). Defining versus describing the nature of science: A pragmatic analysis for classroom teachers and science educators. Science Education, 83, 493509. 